\title{
A Sociolinguistic Approach to the Persian Native Speakers' Strategies for Expressing Sorrow and Happiness: A Comparison of the Gender Differences
}

\author{
Mostafa Rahimi Rad \\ Department of English Languages, Allameh Tabataba'i University, Tehran, Iran \\ Email address: \\ Mostafa.rahimi@yahoo.com \\ To cite this article: \\ Mostafa Rahimi Rad. A Sociolinguistic Approach to the Persian Native Speakers' Strategies for Expressing Sorrow and Happiness: A \\ Comparison of the Gender Differences. International Journal of Education, Culture and Society. Vol. 6, No. 1, 2018, pp. 19-27. \\ doi: $10.11648 /$ j.ijla.20180601.14
}

Received: March 19, 2018; Accepted: April 28, 2018; Published: May 21, 2018

\begin{abstract}
This study aimed to investigate the strategies adopted by Persian native speakers for expressing their happiness and sorrow. For this purpose, the researcher spent one month observing the behavior of different male and female native speakers of Farsi who were of different ages between 12-68. The researcher collected the data either by participating different events of happiness and sorrow or putting the audience under one of these circumstances by giving them some good or bad news in order to audit their way of expressing happiness and sorrow. The responses collected were extracted as 8 happiness expression strategies (surprise, positive adjectives, appreciation, thanking God, expressing emotions and statements and informal emotional expression) and 6 sorrow-expression strategies (expressing pity, questions, statements, curse words and threatening). Among these strategies, statement was common in both happiness and sorrow strategies. After identifying the strategies, the number and percentage of each strategy was calculated for male and female participants. The results indicated that surprise, thanking God, statements and appreciation are the most frequent happiness strategies among male participants and expressing emotions and surprise are the most frequently-used happiness strategies among female ones. One important point in the strategy of "expressing emotion" is that it is a female-specific strategy not used by male population at all. On the other hand, regarding expressions of sorrow, according to the findings of this research, expressing pity is the most frequent strategy both for males and females. In expressing sorrow, using curse words is the second rank for male participants and other strategies are somehow equally-used among both groups as the difference between the frequencies of male and female was not that considerable.
\end{abstract}

Keywords: Happiness Strategies, Sorrow Strategies, Sociolinguistics, Gender

\section{Introduction}

The ability to express emotional states is a central fact in human life and a great number of researches have been focused on the relationship between emotions and nonverbal behaviors, however, as mentioned by Hancock [2007], few researches have examined how emotions are reflected verbally. Happiness and sadness are the most common emotions to be expressed all over the word; however the way to do so is different among cultures. For example, Iranian culture is much different from that of American in a way that the former prefer to express their feelings more emotionally than the latter; i.e. the Iranian tend to exaggerate more than western societies. Thus, the strategies Iranian EFL students adopt are according to their emotional culture.

On the other hand, expressing emotions is different for different genders. As O'Kearney [2004, p. 916] mentions, "references to other-directed negative emotions (e.g., anger) were predominant for boys, and inner-directed negative emotions (such as sadness, fear, guilt, and shame) were characteristic of girls." Males are educated to hide their real feelings and do not express their emotion easily. Memories of past experiences are quite important in our daily lives, and we usually examine ourselves in terms of our past life to bring us a better future. Women and men differ in the narrative description about their life. Bauer, Stennes, and 
Haight [2003, p. 28] state: "women tend to provide narratives that are longer, more detailed and vivid; women tend to include more emotional content in their autobiographical memories." Women also recall more emotional memories and need less time to report their memories than men. Considering the above mentioned points, the aim of this study is to examine the strategies native speakers adopt for expressing emotions in their native language. On the other hand, the researcher has tried to also focus on the gender differences in expressing ones' emotions.

\section{Review of Literature}

The linguistic representations of emotions may have important implications for self-awareness development and emotional experiences regulation. O'Kearney [2004, p. 915] says in his study, "there are clear gender differences in emotion display rules with males preferring behavioral and action/expressive modes and women preferring verbal and facial expressive mode." Males focused less on the consequences and resolution of conflict than women and have a higher priority for more immediate, behavioral representations of their emotional responses.

From the semantic point of view, all women mention some objects or issues associated with emotions while men like to keep within the emotion category. In this study, Vainik [2006, p. 174] states that, "some of the gender-based differences are morphological: among the words mentioned by men, there are some adjectives and a verbal noun, whereas the words mentioned by women only include some plural nouns." According to Bauer et al. [2003, p. 27], "the category of internal states terms is found to be more coherent for women than for men." That is, women use more emotion terms in their descriptions of events from later in life than men.

Moreover, Schirmer, Zysset, Kotz, and Cramon [2004, p. 1114] point out, "semantic processing in women is more susceptible to influences from emotional prosody than is semantic processing in men." The ways of the emotional response variables are in the tendency that women are more emotional than men. Chentsova-Dutton and Tsai [2007, p. 175] say, "according to the emotional behavior and selfreports of emotion, women are supposed to be more emotional than men, even for emotions like anger, for which men are suggested to be more emotional than women." According to Vainik [2006, p. 183], "women are emotionally more competent and more expressive, in particular with verbal expression." Women carry out emotional and linguistic tasks more precisely, as they are more sensitive to that kind of stimuli. O'Kearney [2004, p. 916] suggests, "females more frequently report or express emotion terms referring to inner-directed emotions and also more intense positive and negative feelings."

In some research, we can find the parents' effects on the emotional development of children of different genders. Aldrich and Tenenbaum [2006, p.776] state that parents have more discussion about emotion with girls, therefore girls may discuss emotions more than boys. Holm (2001, p. 385) reports "with the exception of anger, girls are encouraged to learn to express their feelings through words and facial expressions, while boys are discouraged from doing so." That is, boys learn to act on their feelings rather than to talk about them. Vainik [2006, p.183] states, "in bringing up girls, mothers always use more positive emotion words, turning a lot of detailed attention to their emotional states, whereas with boys the focus tends to be on causes and consequences." Since girls hear and use a larger and more varied vocabulary for emotional experiences, they may understand past emotions as being more personally meaningful, and view their past experiences as more emotionally diverse than boys do.

Most of the studies relating to gender differences in emotion expression consider the ways emotions are expressed in a broad sense rather than considering the language in which emotions are talked about. According to Bajgar, Lane and Deane [2005], men have lower emotion awareness than women. Their study was done in accordance with the levels of emotional awareness scale (LEAS) which is a way to measure individual differences in adults' emotional awareness. Hubbard [2001] states that boys will express more sadness and anger than girls who may be more concerned with harmonious relationships.

On the other hand, Chaplin [2006] mentions that emotion development may influence the development of autonomy and identity during adolescence. According to Vainik (2006), women have better competence in emotion with higher productivity in emotional words. However Fischer [1995] as cited in Vainik [2006], states that although the women's emotion words are more active, there is no significant difference in the basic level emotion concepts of different genders. Furthermore, O'Kearney [2004, p. 916] mentions, "references to other-directed negative emotions (e.g., anger) were predominant for boys, and inner-directed negative emotions (such as sadness, fear, guilt, and shame) were characteristic of girls." Males are educated to hide their real feelings and do not express their emotion easily. Memories of past experiences are quite important in our daily lives, and we usually examine ourselves in terms of our past life to bring us a better future. Women and men differ in the narrative description about their life. Bauer, Stennes, and Haight [2003, p. 28] state, "women tend to provide narratives that are longer, more detailed and vivid; women tend to include more emotional content in their autobiographical memories." Women also recall more emotional memories and need less time to report their memories than men. As mentioned above, although a lot of research has been performed on nonverbal expressions of emotion, few have concentrated on verbal expression of feelings.

A simple surf on the net will give the researcher several papers on different speech acts such as refusal, thanking, etc. some of which are listed below:

The first study was done by 2 Iranian $\mathrm{PhD}$ students, sadeghi \& Savojbolaghchilar [2011] which was aimed to compare the refusal strategies used by four groups of native and nonnative speakers of English, namely, American 
English speakers, Persian/Azeri speakers with little working knowledge of English, advanced Iranian learners of English, and Iranians living in the U.S. for an average of 10 years. A Discourse Completion Test (DCT) developed by Beebe, Takahashi and Uliss-Welts [1990] was used to elicit the relevant data. The analysis showed that generally speaking, Iranian residents and advanced learners used different strategies to refuse requests, invitations, offers and suggestion from Iranians living aboard who acted more similarly to native speakers living in the U.S. More detailed findings and implications are discussed in the paper.

The second study selected to be brought here aimed to compare gender-related differences in the use of emotion terms and the correspondence between semantic emotion knowledge and episodic emotion experience, with the method of testing participant's episodic emotion experience (basic knowledge being made up of whatever happens to be the most frequent and impressive in everyday experience). Thirty participants are recruited for two list tasks, a Free Listing task and a Recent Experience task. The results show that (1) for both men and women the most salient emotion words present an antonymic pair-sadness-happiness. (2) Some of the gender-based differences are morphological. The female participants tend to use adjectives and verbs while most of the words mentioned by the males are nouns. (3) Women tend to mention objects or issues associated with emotions while men prefer to keep within the emotion category. Finally, when men recall their past experience, they tend to use positive words while women use both positive as well as negative words.

One of the papers written in this subject is by Hancock et al [2007] focusing on expressing emotions in text-based communication. The study examines how people express and detect emotions during text-based communication (instant messaging), an environment that eliminates the nonverbal cues typically associated with emotion. The results from 40 interactions suggest that users relied on four strategies to express happiness versus sadness, including disagreement, negative affect terms, punctuation, and verbosity.

\section{Methodology}

This section is presented in 2 subsections: Data collection and data analysis the details of which are provided below:

\subsection{Participants}

The participants of this research were 100 Iranian native speakers in Tehran. These participants were selected in 2 groups of male and female of ages between 12-68.

\subsection{Data Collection}

Unlike the similar studies done up to the present time on this subject, the current survey has been performed via real data collection, i.e. the researcher has participated different events of happiness and sorrow or has put the audience under one of these circumstances by giving them some good or bad news in order to audit their way of expressing happiness and sorrow. The responses collected in this way are provided attached to this article.

\subsection{Data Analysis}

After the data was collected via the above-mentioned method, it was turn to analyze the data. For this purpose, the responses of the sample group were tried to be categorized in both groups of items (happiness situations and sorrow ones) into several strategies, i.e. the responses were fallen into some strategies by the researcher. Then the number and percentage of each strategy was calculated for 2 groups of participants: male and female. The results are provided in the following section.

\subsection{Limitations of the Study}

This study had some limitations as follows:

The first limitation in performing this research was the number of participants, which limited the scope of research. The second limitation was the lack of time that caused some deficiencies in writing the paper.

\subsection{Results and Discussions}

As mentioned above, the collected data was analyzed to extract some strategies out of it. The strategies, participants adopted for expressing their emotions of happiness and sorrow are provided as follows which have been approved by one of the professors teaching at Islamic Azad University, Tehran Central Branch:

\section{Strategies for Expression of Happiness}

Results of the study indicated that expressing happiness can be done via 8 strategies as follows:

1) Surprise:

The first strategy used was the one containing terms of surprise. Some examples of this strategy are:

Go away;

Are you telling lie

The results indicate that the frequency of this strategy was counted 7 among male participants, and 10 among female ones. This result proves that women are more eager to use this strategy which $\backslash$ is an emotion-based one than men. Of course as the difference is not considerable, this strategy cannot be counted as a female strategy.

2) Positive adjectives:

This strategy included some adjectives to express one's happiness. For instance:

How are you kind;

How it is perfect.

The frequency of this strategy was counted equally 5 $(12.5 \%)$ among male and female participants which indicates that the tendency of using it is shared among men and women.

3) Appreciation:

In the situations of happiness, the subjects tried to use the 
terms applied for appreciation, for example:

Bully for you;

It is great, Thanks

The frequency of adopting the strategy of appreciation was 8 for male and 6 for female participants which is somehow like the first strategy (surprise).

4) Thanking God:

In addition to the third strategy which was appreciating someone, some people tried to use some expressions for thanking the origin of happiness, i.e. God, by the use of following terms:

Thanks God.

Number of male participants adopting this strategy was 7, as the frequency of it among female ones which is again similar to the second strategy (positive adjectives).

5) Questions:

This category included the attempt of students to use questions indicating that they have not believed what was told to them. For example:

Are you pulling my legs?

IS it right?

Are you playing tricks on me?

According to the results of this study, male participants tend to use this strategy twice more than the female participants and this proves that it can be considered a male strategy, due to the fact that men have a more analytical nature.

6) Expressing emotions:

Some of the participants tried the strategy including some expression of feelings. For example:

Wow.I really love you and so on.

As can be seen in the statistics of this study, no male participant adopted this strategy. However 9 female participants tend to use this strategy. As can be realized from the name, expressing emotions is an emotional strategy which somehow lends it to female world. Thus this can justify why it is mostly adopted by the female population.

7) Statement:

By statement, we mean uttering some sentences for displaying one's happiness. For example:

Well that's great!

How long have I been waiting for this day!

It was very beautiful!

According to the results of the study, statement was used by 7 male participants and 6 female one.

8) Using informal emotional terms:

This strategy was adopted by the younger participants who were shown to be more energetic in expressing their happiness. Some instances include:

Horaaaaaaaaaaaa!

That is perfect.

According to the results of this study, 10 male participants and 4 females used this strategy which proves that male participants tend to use this strategy twice more than the female participants and this proves that it can be considered a male strategy.

More details of the happiness strategies results can be seen in table 1 and figure 1.

Table 1. Numbers and percentage of happiness expression strategies.

\begin{tabular}{lllll}
\hline \multirow{2}{*}{ Strategy (Happiness) } & \multicolumn{3}{c}{ Male } & \multicolumn{3}{l}{ Female } \\
\cline { 2 - 5 } & No & \% & No & \% \\
\hline Surprise & 7 & 15 & 10 & 19 \\
Positive adjectives & 5 & 11 & 5 & 10 \\
Appreciation & 8 & 17 & 6 & 11 \\
Thanking God & 7 & 15 & 7 & 14 \\
Question & 3 & 6 & 6 & 11 \\
Expressing emotion & 0 & 0 & 9 & 17 \\
Statement & 7 & 15 & 6 & 11 \\
Informal emotional utterances & 10 & 21 & 4 & 7 \\
Total & 47 & 100 & 53 & 100 \\
\hline
\end{tabular}

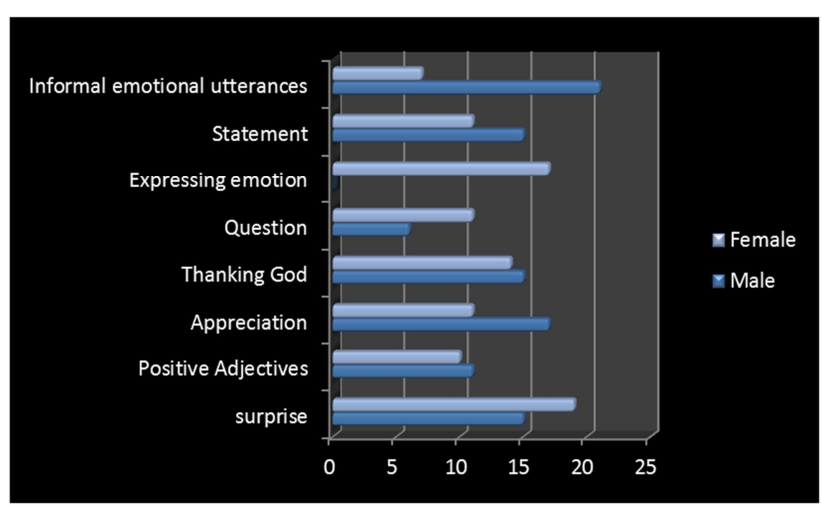

Figure 1. Numbers and Percentage of Happiness Expression Strategies.

\section{Strategies for Expression of Sorrow}

According to the results obtained from the experiment, 6 strategies were identified for expressing sorrow among the participants on the current study. These strategies include:

1) Expressing pity:

Those adopting this strategy were trying to show their sadness by the use of condolence words. Some examples are as follows:

Oh I did not know!

How awful!

How pity.

The results, as can be seen in table 1, indicate that 20 male participants and 25 female ones adopted this strategy in expressing their sorrow. The difference is not so considerable to tend it towards male or female side.

2) Questions:

Like the similar strategy in happiness category, this strategy is adopted by the students to use questions indicating that they have not believed what was told to them. For example:

How did this happen?

What's this world?

As indicated in the results of this study, 10 male and 12 female participants used this strategy and like the previous strategy in expressing sorrow, there is no considerable difference among male and female population.

3) Statement:

By statement, we mean uttering some sentences for 
displaying one's sorrow. For example:

Have fun just!

Life is not really worth living/

This strategy has a frequency of 7 among male and 8 among female participants.

4) Using curse words:

This strategy was adopted by those subjects who were irritated by the sad news. Examples are:

Shits to this life;

Fuck this life;

How hell is this world.

12 male and 5 female participants adopted this strategy.

5) Threatening:

This strategy was used just once by one of the samples who was quite angry with the person causing the trouble. He used:

Fuck your mother,

Thus this strategy cannot be counted as a generalizable one.

The details of numbers and percentage of each sorrow expression strategy among male and female participants are provided in table and figure 2 .

As it can be seen in table 1, the first commonly-used strategies among male participants were Appreciation and question with frequency of 20 percent. However, the most frequent strategy among female participants was "surprise" with a frequency of 25 percent.

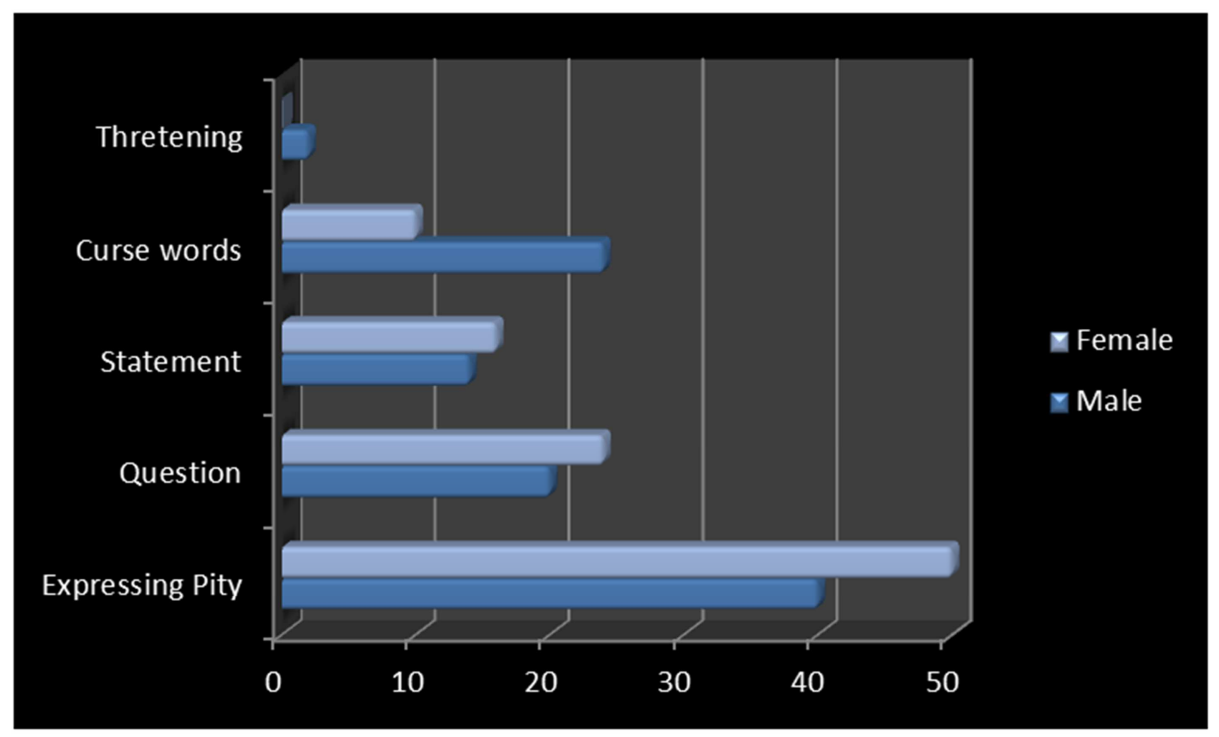

Figure 2. Numbers and Percentage of Sorrow Expression Strategies.

Table 2. Numbers and Percentage of Sorrow Expression Strategies.

\begin{tabular}{lllll}
\hline \multirow{2}{*}{ Strategy (Sorrow) } & \multicolumn{3}{l}{ Male } & \multicolumn{3}{l}{ Female } \\
\cline { 2 - 5 } & No & \% & No & \% \\
\hline Expressing pity & 20 & $40 \%$ & 25 & $50 \%$ \\
Questions & 10 & $20 \%$ & 12 & $24 \%$ \\
Statement & 7 & $14 \%$ & 8 & $16 \%$ \\
Curse words & 12 & $24 \%$ & 5 & $10 \%$ \\
Threatening & 1 & $2 \%$ & 0 & $0 \%$ \\
Total & 50 & 100 & 50 & 100 \\
\hline
\end{tabular}

\section{Conclusion}

This study aimed to investigate the strategies adopted by Persian native speakers for expressing their happiness and sorrow. For this purpose, the researcher spent one month observing the behavior of different male and female native speakers of Farsi who were of different ages between 12 - 68 . The researcher collected the data either by participating different events of happiness and sorrow or putting the audience under one of these circumstances by giving them some good or bad news in order to audit their way of expressing happiness and sorrow. The responses collected were extracted as 8 happiness expression strategies (surprise, positive adjectives, appreciation, thanking God, expressing emotions and statements and informal emotional expression) and 6 sorrow-expression strategies (expressing pity, questions, statements, curse words and threatening). Among these strategies, statement was common in both happiness and sorrow strategies. After identifying the strategies, the number and percentage of each strategy was calculated for male and female participants. The results indicated that surprise, thanking God, statements and appreciation are the most frequent happiness strategies among male participants and expressing emotions and surprise are the most frequently-used happiness strategies among female ones. One important point in the strategy of "expressing emotion" is that it is a female-specific strategy not used by male population at all.On the other hand, regarding expressions of sorrow, according to the findings of this research, expressing pity is the most frequent strategy both for males and females.In expressing sorrow, using curse words is the second rank for male participants and other strategies are somehow equally-used among both groups as the difference between the frequencies of male and female was not that considerable. 


\section{Appendix}

\begin{tabular}{|c|c|c|c|c|}
\hline رديف & سن & جنسيت & شغل & غم \\
\hline 1 & 25 & مرد & دانشجو & بيجاره شُدم \\
\hline 2 & 20 & زن & دانشجو & خاك بر سرم \\
\hline 3 & 28 & زن & مدرس دانشخاه & جقدر همه جِيز سخت شده \\
\hline 4 & 30 & زن & مترجم & جر ا اينطورى شد؟ \\
\hline 5 & 22 & زن & 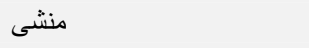 & ل \\
\hline 6 & 20 & مرد & دانشجو & شانس كند منو مى بينى؟ \\
\hline 7 & 18 & ن ان & دانش آموز & و |||||||||||| \\
\hline 8 & 18 & 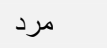 & دانش آموز & ن نه888880 \\
\hline 9 & 26 & 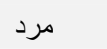 & مهندس نرم افزار & اى خدا! \\
\hline 10 & 35 & زن & يزشى & عجب! \\
\hline 11 & 46 & مرد مرد & فروشنده & بيجاره شدم كه! \\
\hline 12 & 20 & ن & دانشجو & دروغ مى گَ؟؟ \\
\hline 13 & 15 & زن & دانش آموز & دلم داره مى تركه! \\
\hline 14 & 23 & 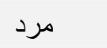 & دانشجو & يا على! \\
\hline 15 & 28 & مرد مرد & مهندس شيمى & $!$ \\
\hline 16 & 32 & 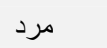 & مرندس شيمى & نه بابا! راست مى گحى؟ \\
\hline 17 & 41 & ن ان & 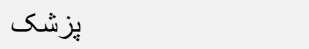 & جر ا اينطورى شد آخه؟ \\
\hline 18 & 32 & مرد مرد & كارشناس فروش & شانسو داشته باش فقط! \\
\hline 19 & 25 & ن ان & كارشناس فروش & حالا جى مبشه؟ \\
\hline 20 & 29 & 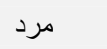 & ت تحليلكر & شوخى نكن تو رو خدا! \\
\hline 21 & 35 & 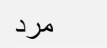 & تحليلكر & و واى جر ا؟ \\
\hline 22 & 26 & ن ان & مترجم & كاش مى مردم راحت مى شدم \\
\hline 23 & 28 & 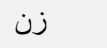 & مدرس & جقدر مسخره \\
\hline 24 & 31 & 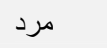 & مدرس دانشخاه & عجب جريانى شد! \\
\hline 25 & 50 & ن ان & 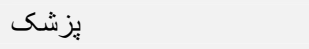 & جقدر بد \\
\hline 26 & 56 & 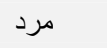 & يزشى & عجب! \\
\hline 27 & 29 & 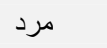 & مهندس معمار & راست مى گى؟؟ \\
\hline 28 & 29 & 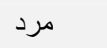 & مهندس معمار & ج جَ ا؟؟ \\
\hline 29 & 36 & 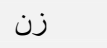 & مدرس زبان & الهى بميرم \\
\hline 30 & 24 & 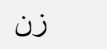 & فروشنده & مطمئنى؟ \\
\hline 31 & 28 & 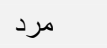 & مدرس & شوخى مى كنى! \\
\hline 32 & 19 & 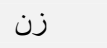 & 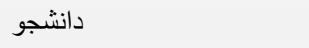 & نكو نو رو خدا! \\
\hline 33 & 31 & 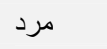 & مهندس متالوزى & نها! \\
\hline 34 & 26 & ن ان & مترجم شفاهى & جقدر نار احت كننده! \\
\hline 35 & 28 & ن ان & مترجم شفاهى & عجب آدمايى! \\
\hline 36 & 29 & 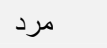 & فروشنده باز ار & كند بزنن به اين دنيا \\
\hline 37 & 24 & 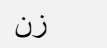 & د دانشجو & همه جى كند خورد! \\
\hline 38 & 30 & 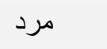 & مدرس & مطمئنيد؟ \\
\hline 39 & 32 & ن ان & مدرس & جر ||l|!؟ \\
\hline 40 & 35 & 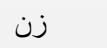 & مترجم & جقدر اسف بار ! \\
\hline 41 & 65 & 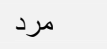 & بازنشسته بانك & برووو! \\
\hline 42 & 54 & 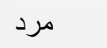 & بازنشسته بانك & نه بابا! \\
\hline 43 & 52 & 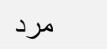 & بازنشسته آموزش و بروزش & حالا جى كار مى كنى؟ \\
\hline 44 & 32 & 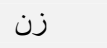 & كارمند & دلم دارٍِ مى تركه! \\
\hline 45 & 39 & 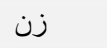 & كارمند بانك & زندكى و اقعاً نمى ارزه! \\
\hline 46 & 52 & ن ان & خانه دار & و و \\
\hline 47 & 26 & 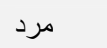 & دييلمه بيكار & اين شانس ماست ديخه \\
\hline 48 & 29 & 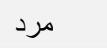 & مهندس شيمى & كند خورد به برنامه هام \\
\hline 49 & 36 & 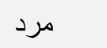 & مهندس معمار & ر راست مى گى؟ \\
\hline 50 & 40 & 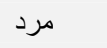 & كارمند شركت نفت & 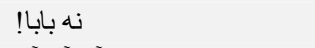 \\
\hline 51 & 28 & 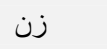 & خانه دار & آخ آخ آخ \\
\hline 52 & 33 & مرد مرد & كارمند & جه بد جإ \\
\hline 53 & 36 & 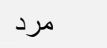 & كارمند & اي داد بيداد \\
\hline 54 & 50 & زن & معلم & و و|||||||||||||| \\
\hline 55 & 59 & 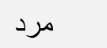 & كارشناس برق & اى كاش اينطورى نمى شد \\
\hline 56 & 36 & 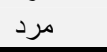 & فروشنده & كاش اين كارو نمى كردى \\
\hline
\end{tabular}




\begin{tabular}{|c|c|c|c|c|}
\hline رديف & سن & جنسيت & 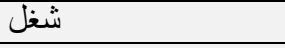 & غم \\
\hline 57 & 29 & مرد & فروشنده & جقدر ضايع \\
\hline 58 & 56 & 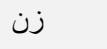 & خانه دار & خيلى بد شد \\
\hline 59 & 80 & 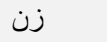 & 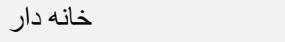 & تو رو خدا نكو !!! \\
\hline 60 & 43 & مرد & 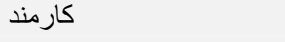 & خيلى ضايع شد \\
\hline 61 & 29 & 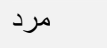 & مهندس شيمى & بد خر اب شديم \\
\hline 62 & 36 & 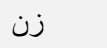 & 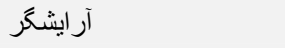 & دلم خيلى سوخت \\
\hline 63 & 19 & ت ان & دانشجو & |||||||||||||||||||||| \\
\hline 64 & 25 & 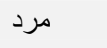 & 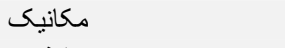 & و والاويلا \\
\hline 65 & 23 & 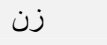 & دانشجو & اى داد بيدا|l \\
\hline 66 & 48 & 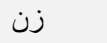 & خانه دار & حالا كى مسئوليتشو قبول مى كند؟ \\
\hline 67 & 27 & 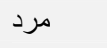 & مهندس نرم افزار & اي داد \\
\hline 68 & 24 & ن ان ان & تحليلكر كسب و كار & و واى واى واى \\
\hline 69 & 25 & 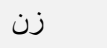 & دانشجو & خيلى نار احتش شدم \\
\hline 70 & 26 & 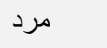 & دانشجو & جقدر بد \\
\hline 71 & 54 & 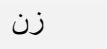 & خانه دار & كاش اينطورى تموم نميشد \\
\hline 72 & 28 & 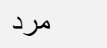 & مدرس دانشخاه & جر ا ينجورى شد \\
\hline 73 & 62 & 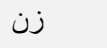 & خانه دار & محكه من جه كناهى كردم \\
\hline 74 & 32 & 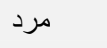 & 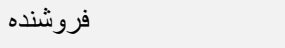 & ن \\
\hline 75 & 38 & 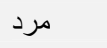 & كارمند & جر |ll آخه؟ \\
\hline 76 & 20 & مرد & دانشجو & جطورى دلت اومد اين كارو بكنى؟ \\
\hline 77 & 16 & 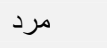 & دانش آموز & اينم شانس منه ديخه \\
\hline 78 & 32 & 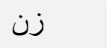 & مهندس معمارى & دروغ ميكى؟ \\
\hline 79 & 30 & 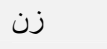 & مهندس معمارى & 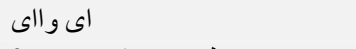 \\
\hline 80 & 26 & 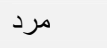 & 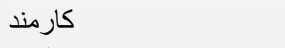 & جطورى بهش خبر بدم؟ \\
\hline 81 & 19 & 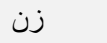 & دانشجو & 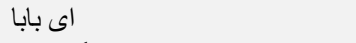 \\
\hline 82 & 17 & 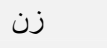 & دانش آموز & ن نكوووو! \\
\hline 83 & 25 & مرد & كارشناس فروش & خجالت نكشيد اين كارو كرد؟ \\
\hline 84 & 36 & 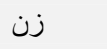 & مربى ورزش & $خ^{\top}$ \\
\hline 85 & 39 & 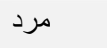 & فروشنده & ايى داد بيداد \\
\hline 86 & 28 & 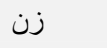 & فروشنده & و من \\
\hline 87 & 21 & 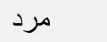 & دانشجو & ol \\
\hline 88 & 60 & 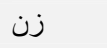 & آر ايشكر & آخ خدا \\
\hline 89 & 36 & 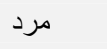 & غريق نجات & آخه جֶر ا؟ \\
\hline 90 & 35 & 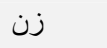 & 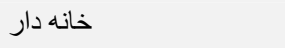 & آخ آخ آخ \\
\hline 91 & 26 & 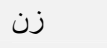 & دانشجوى كارشناسى ارشد & دلم كرفت \\
\hline 92 & 48 & 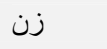 & خانه دار & و واى خدا! \\
\hline 93 & 26 & 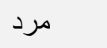 & فروشنده & تر زده شد بهش بابا! \\
\hline 94 & 23 & 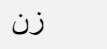 & دانشجو & تو روح! \\
\hline 95 & 12 & مرد & دانش آموز & اى واى حالا جِى كار كنم؟ \\
\hline 96 & 18 & 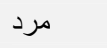 & دانشجو & عين سخ يشيمونم! \\
\hline 97 & 26 & ن ت ان & دانشجو & اي بابا \\
\hline 98 & 41 & 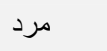 & كارمند & بدرمو در آورديد كه بابا! \\
\hline 99 & 25 & 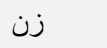 & 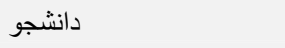 & و واى واى! \\
\hline 100 & 35 & مرد & دانشجو & مادرشو به عز اش ميشونم \\
\hline رديف & سن & جنسيت & شخل & شادى \\
\hline 1 & 25 & مرد & دانشجو & هى واى من \\
\hline 2 & 20 & ن ان & دانشجو & راضى ام ازت \\
\hline 3 & 28 & زن & مدرس دانشخاه & خيلى خوشحالم \\
\hline 4 & 30 & زن & 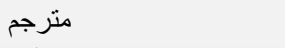 & جقدر عالى شد \\
\hline 5 & 22 & ن ان & 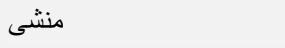 & تو رو قرآن؟ \\
\hline 6 & 20 & 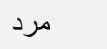 & دانشجو & دمت كرم بابا \\
\hline 7 & 18 & 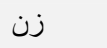 & دانش آموز & عاشقتم \\
\hline 8 & 18 & 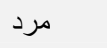 & دانش آموز & دمم كرم \\
\hline 9 & 26 & مرد مرد & مهندس نرم افزار & لامصب عاليه \\
\hline 10 & 35 & ن ت ن & يزشى & جدا؟ \\
\hline 11 & 46 & 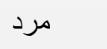 & فروشنده & خيلى حال دادى بابا \\
\hline 12 & 20 & زن & دانشجو & آخ جووون \\
\hline
\end{tabular}




\begin{tabular}{|c|c|c|c|c|}
\hline رديف & سن & جنسيت & شغل & شادى \\
\hline 13 & 15 & زن & دانش آموز & ايو الله \\
\hline 14 & 23 & 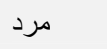 & دانشجو & جقدر خوب \\
\hline 15 & 28 & 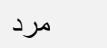 & مهندس شيمى & و اقعاً دارى ميكى؟؟ \\
\hline 16 & 32 & 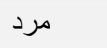 & مهندس شيمى & خداى من شكرت \\
\hline 17 & 41 & ن ت ن & 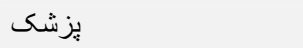 & خب اين كه خبلى عاليه \\
\hline 18 & 32 & 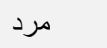 & كارشناس فروش & دستت درست \\
\hline 19 & 25 & زن - ت & كارشناس فروش & راست مى گى؟ \\
\hline 20 & 29 & 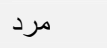 & تحليلكر & بابا شوخى مى كنى! \\
\hline 21 & 35 & 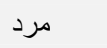 & تحليلكر & ل إى جونم \\
\hline 22 & 26 & ن & مترجم & جقدر خوب شد \\
\hline 23 & 28 & زن & مدرس & ل برفكت \\
\hline 24 & 31 & 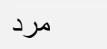 & مدرس دانشخاه & و ا'الى جقدر عالى \\
\hline 25 & 50 & ن ان & يزشى & خب خدا رو شكر \\
\hline 26 & 56 & 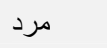 & يزشى & خوشحالم بر اتون \\
\hline 27 & 29 & 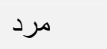 & مهندس معمار & برووووو! \\
\hline 28 & 29 & مرد مرد & مهندس معمار & هور ||||| \\
\hline 29 & 36 & زن ان ا & مدرس زبان & بكو جان تو!! \\
\hline 30 & 24 & ن ال & فروشنده & راست مى گى؟؟ \\
\hline 31 & 28 & 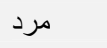 & مدرس & 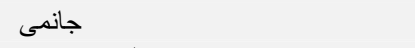 \\
\hline 32 & 19 & 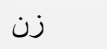 & 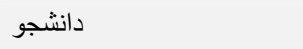 & درى درى درى (به حالت ريتميك) \\
\hline 33 & 31 & 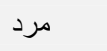 & مهندس متالوزى & 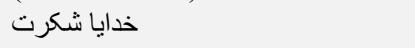 \\
\hline 34 & 26 & 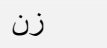 & 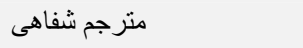 & دستت درد نكنه \\
\hline 35 & 28 & 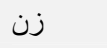 & مترجم شفاهى & خيلى خوشحال شدم به خدا \\
\hline 36 & 29 & 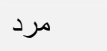 & فروشنده باز ار & و ||||||||| جقدر منتظر اين روز بودم \\
\hline 37 & 24 & 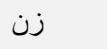 & 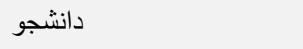 & كارت درسته \\
\hline 38 & 30 & 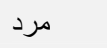 & 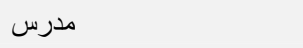 & آفرين \\
\hline 39 & 32 & 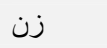 & مدرس & جقدر جالب \\
\hline 40 & 35 & 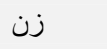 & 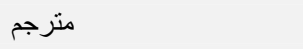 & و اقعاً ميكى؟ \\
\hline 41 & 65 & 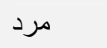 & بازنشسته بانك & خبلى خوبه \\
\hline 42 & 54 & 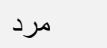 & بازنشسته بانك & خوب شد بابا \\
\hline 43 & 52 & 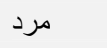 & بازنشسته آموزش و بِروزش & تو رو قرآن؟ \\
\hline 44 & 32 & 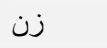 & 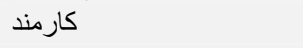 & برو بابا! راست ميكى؟ \\
\hline 45 & 39 & 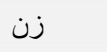 & كارمند بانى & و ||||||||||||||||||| جقدر خووووب \\
\hline 46 & 52 & ت إن & خانه دار & 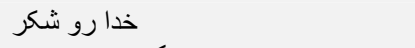 \\
\hline 47 & 26 & 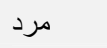 & ديبلمه بيكار & بكو جون مامانم! \\
\hline 48 & 29 & 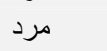 & مهندس شيمى & آفرين آفرين \\
\hline 49 & 36 & 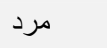 & مهندس معمار & | ||||||||||||||||||||||||| || || \\
\hline 50 & 40 & 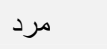 & كار مند شركت نفت & ايول بابا! \\
\hline 51 & 28 & 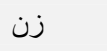 & 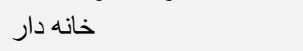 & 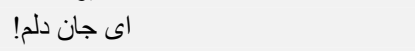 \\
\hline 52 & 33 & مرد اد & كارمند & خيلى عالى شد \\
\hline 53 & 36 & 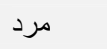 & 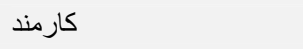 & آفرين! \\
\hline 54 & 50 & 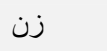 & 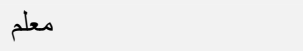 & خيلى خبر خوبى دادى! \\
\hline 55 & 59 & 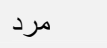 & كارشناس برق & بسيار هم خوب! \\
\hline 56 & 36 & مرد اد & فروشنده & عمراً بذارم اين فرصت از دستم بره \\
\hline 57 & 29 & 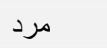 & فروشنده & 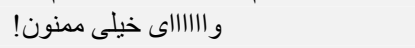 \\
\hline 58 & 56 & 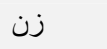 & خانه دار & تِ تو رو قرآن؟ \\
\hline 59 & 80 & 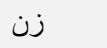 & خانه دار & و اقعاً ازت ممنونم! \\
\hline 60 & 43 & 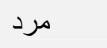 & كارمند & خدايا شكرت! \\
\hline 61 & 29 & 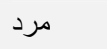 & مهندس شيمى & يه عمر مديونتم! \\
\hline 62 & 36 & 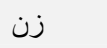 & آر آيشكر & خيلى عالى شد! \\
\hline 63 & 19 & ن ت ان & مانشجو & جقدر مهربونى! \\
\hline 64 & 25 & 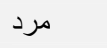 & 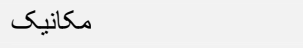 & دروغ ميحى؟ \\
\hline 65 & 23 & 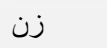 & 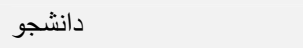 & بكو جون من! \\
\hline 66 & 48 & 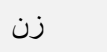 & خانه دار & انقدر خوشحال شدم خو اب از سرم بريد! \\
\hline 67 & 27 & 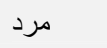 & مهندس نرم افزار & ر راست ميكى؟ \\
\hline 68 & 24 & 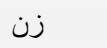 & تحليلكر كسب و كار & منو بكو فكر كردم قبول نميشم! \\
\hline 69 & 25 & ن ان ان & دانشجو & جييييييييييييغ \\
\hline 70 & 26 & 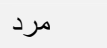 & 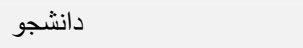 & 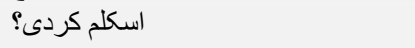 \\
\hline 71 & 54 & ن & خانه دار & و الاى خبلى خوب شد كه! \\
\hline
\end{tabular}




\begin{tabular}{|c|c|c|c|c|}
\hline رديف & سن & جنسيت & شغل & شادى \\
\hline 72 & 28 & مرد & مدرس دانشكاه & بسيار خوب كارى كردى! \\
\hline 73 & 62 & زن - ت ان & خانه دار & عاالى شد! \\
\hline 74 & 32 & 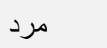 & فروشنده & خدايا شكرت! \\
\hline 75 & 38 & 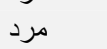 & كارمند & و والاllig \\
\hline 76 & 20 & 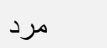 & دانشجو & كارت دسته بابا \\
\hline 77 & 16 & 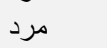 & دانش آموز & كاش همه مث تو بودن \\
\hline 78 & 32 & 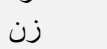 & مهندس معمارى & جقدر مهربون! \\
\hline 79 & 30 & 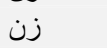 & مهندس معمارى & و الا'اى مردم از خوشحالى! \\
\hline 80 & 26 & 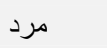 & كارمند & آورين آورين! \\
\hline 81 & 19 & زن - ت ن & دانشجو & آخ جون \\
\hline 82 & 17 & 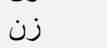 & دانش آموز & جانمى جان \\
\hline 83 & 25 & 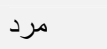 & كارشناس فروش & داداش ممنون \\
\hline 84 & 36 & 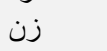 & مربى ورزش & آفرين \\
\hline 85 & 39 & مرد & فروشنده & خيلى حال دادى \\
\hline 86 & 28 & زن - ت ان & فروشنده & از خوشحاليت خيلى خوشحالم \\
\hline 87 & 21 & 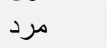 & دانشجو & 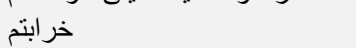 \\
\hline 88 & 60 & زن - ت ان & آرايشكر & الان ميميرم از خوشحالى \\
\hline 89 & 36 & 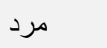 & غريق نجات & برو حالثو ببر \\
\hline 90 & 35 & زن - ت ان & خانه دار & خيلى كار قثنـحى بود \\
\hline 91 & 26 & زن - تان & دانثجوى كارشناسى ارشد & خيلى حركت زيبايى بود \\
\hline 92 & 48 & زن & خانه دار & خدايا ممنونتم \\
\hline 93 & 26 & 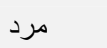 & فروشنده & بابا كار درست!! \\
\hline 94 & 23 & زن - ت ان & 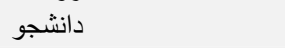 & واى جقدر تو دوست خوبى هستى! \\
\hline 95 & 12 & 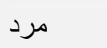 & دانش آموز & 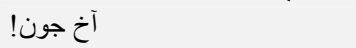 \\
\hline 96 & 18 & 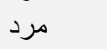 & 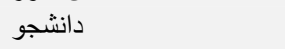 & جون داداش! \\
\hline 97 & 26 & زن - ت ان & دانشجو & و اقعاً اين كارو مى كنى؟ \\
\hline 98 & 41 & زن - تان & 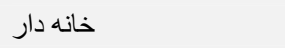 & من به نو افتخار ميكنم \\
\hline 99 & 25 & زن - ت ان & دانشجو & خيلى ازت ممنونم \\
\hline 100 & 35 & 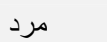 & دانشجو & باريك اله \\
\hline
\end{tabular}

[8] Bajgar, J., Ciarrochi, J., Lane, R., \& Deane, F. (2005). Development of the levels of emotional awareness scale for children (LEAS-C). British Journal of Developmental Psychology, 23(4), 569-586.

\section{References}

[1] Behr, N. (2012). "Mnemonic Techniques in L2 Vocabulary Acquisition." Retrieved from http://mdh.divaportal.org/smash/get/diva2:616805/FULLTEXT02.pdf

[2] Ellis R. (2001). Introduction: investigating form-focused instruction. Language Learning 51(1): 1-46.

[3] Hancock, J. T. Verbal irony use in computer-mediated and face-to-face conversations. Journal of Language and SocialPsychology, 23 447-463, 2004.

[4] Hancock, J. T. et al, 2007. Expressing emotion in text-based communication, journal of Language and social Psychology,

[5] Sadeghi, K. \&Savojbolaghchilar, S. A comparative study of refusal strategies used by Iranian and Americans. International Journal of Academic Research. Vol. 3, No. 2. March, 2011.

[6] L. Beebe, T. Takahashi and R. Uliss-Weltz. Pragmatic transfer in ESL refusals. In R. Scarcella, E. S. Andersen, and S. D. Krashen, Eds. Developing communicative competence in a second Language (pp. 55-73). Newbury House: New York, 1990, pp. 55-73.

[7] J. Yang. How to say 'No' in Chinese: A pragmatic study of refusal strategies in five TV series. The 20th North American Conference on Chinese linguistics (NACCL-20) The Ohio State University, Ohio, 2008, pp. 1041-1058.
[9] Bauer, P., Stennes, L., \&Haight, J. (2003). Representation of the inner self in autobiography: Women's and men's use of internal states language in personal narratives. Memory, 11(1), $27-42$.

[10] Chaplin, T. (2006). Anger, happiness, and sadness: Associations with depressive symptoms in late adolescence. Journal of Youth \& Adolescence, 35(6), 977-986.

[11] Fischer, A. (1995). Emotion concepts as a function of gender. In J. A. Russell, J.-M. Fernandez-Dols, A. S. R. Manstead, \& J. C. Wellenkamp (Eds.), Everyday conceptions of emotion: an introduction to the psychology, anthropology and linguistics of emotion (pp. 457-474). Dordrecht, Netherlands: Kluwer Academic Publishers.

[12] O'Kearney, R., \&Dadds, M. (2004). Developmental and gender differences in the language for emotions across the adolescent years. Cognition and Emotion, 18(7), 913-938. Schirmer, A., Zysset, S.,

[13] Vainik, E. (2006). Intracultural variation of semantic and episodic emotion knowledge in Estonian. Trames, 10(2), 169189. 